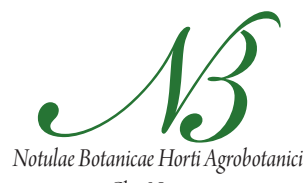

Cluj-Napoca

\title{
Analysis of Chromosome Number in Some Allium and Silene Wild Species with Ornamental Use
}

\author{
Lucia DRAGHIA*, Elena Liliana CHELARIU', Culiță SîRBU², \\ Maria BRÂNZĂ', Cristina SANDU MICULSCHI' \\ ${ }^{1}$ University of Agricultural Sciences and Veterinary Medicine Iaşi, Facultaty of Horticulture, 3, $M$. \\ Sadoveanu Alley, Iasi, Romania; lucia@uaiasi.ro ('corresponding author) \\ ${ }^{2}$ University of Agricultural Sciences and Veterinary Medicine Iaşi, Facultaty of Agriculture, 3, M. Sadoveanu Alley, Iasi, Romania
}

\begin{abstract}
The present study analyses the number of somatic chromosomes in plant species with ornamental value, in Romanian indigenous flora, Allium (A. flavum L., A. saxatile Bieb.) and Silene (S. compacta Fischer., S. supina M.Bieb.). The biological material was identified and harvested in the South-Eastern part of Dobrogea (Tulcea and Constanța counties), area in the South-Eastern part of Romania, situated between the Danube and the Black Sea. Individuals from two populations of Allium flavum and Allium saxatile, respectively from Tulcea county (Turcoaia town) and Constanța county (from Cheile Dobrogei) were analyzed. In the case of Silene compacta and Silene supina, plants of one population in Tulcea county, Turcoaia town, were used. The aim of the analysis was the quantification and comparison of the somatic chromosomes of plants from the same species but different populations, as is the case of the two Allium species, but also to relate them to results from specialty literature, reported by others. The chromosome number was determined in the roots of the small plants that were obtained from seeds collected in their natural habitat. Except the case of Silene supina species, where only diploid forms were identified $(2 \mathrm{n}=24)$, when in specific literature tetraploid forms are mentioned $(2 \mathrm{n}=48)$, found in other areas, all other analyzed taxa register similar data to that reported in other geographic regions. Respectively, $2 \mathrm{n}=16$ in the case of Allium flavum and Allium saxatile and $2 \mathrm{n}=24$ in the case of Silene compacta.
\end{abstract}

Keywords: Allium flavum, Allium saxatile, chromosome numbers, Silene compacta, Silene supina, wild flora of Romania

\section{Introduction}

Romanian flora boasts a wealth and diversity due to geographical, climatic, edaphic and topographic factors specific to SE Europe in general, and the territory of Romania in particular. Studies regarding the chromosomal number in taxa from different ecological areas of Romania have previously been registered by Tăcină (1980) for endemic species (Hepatica transilvanica) and by Băra et al. (2003) for rare species of Romanian flora (Allium flavum ssp. tauricum, Acanthus balcanicus, Asphodeline lutea, Dianthus spiculifolius, Digitalis ferruginea, Galanthus elwesii, Helleborus odorus, Laburnum alpinum, Peltaria alliacea, Petrorhagia saxifraga, Prunus tenella, Alyssum borzeanum, Angelica arhangelica, Dianthus nardiformis, Globularia punctata, Paeonia tenuifolia, Paliurus spina christi, Polemonium coeruleum, Silene nutans ssp. dubia, Veratrum nigrum etc.). Boşcaiu et al. (1999) studied the perennial polyploid taxa of Cerastium from Romania and other $\mathrm{Eu}$ ropean countries, while Baltisberger and Widmer (2009) analyzed from a karyologic point of view Achillea, Antennaria, Centaurea, Gnaphalium, Pilosella, Podospermum, Campanula, Dianthus, Silene, Geranium, Nepeta, Stachys,
Teucrium, Nigritella, Setaria, Aconitum, Consolida, Ranunculus, Geum montanum, Potentilla, Veronica species from different Romanian regions. Similar research was done by Mraz and Szelag (2004) in the case of Hieracium and Pilosella, Brullo et al. (1996) in Allium fuscum, while Jacobsen and Ownbey (1977) and Weimarck (1971) (quoted by Krahulcova, 2003), analyzed Allium flavum and Hierochloë australis.

Dobrogea represents one of the most important Romanian areas in view of its flora and habitat diversity, due to its many ecosystems ranging from steppe, silvo-steppe, forest to aquatic zones, lakes and sea (Sălăgeanu et al., 1973). In this area, around 2000 taxa are found, among which 20 endemic species and over 200 rare plants (Anastasiu and Negrean, 2006). Allium genus (Alliaceae) comprises of approximately 750 species (Stearn, 1992, quoted by Yusaf, 2004), spread all over the Northern hemisphere, from arid subtropical to boreal regions (Fritsch and Friesen, 2002). In the indigenous flora of Romania, a number of 22 species were recorded and 19 in Dobrogea (Oprea, 2005). Allium flavum L. is a geophytic perennial plant, originating from the specific temperate climate area of Europe. In Romania, A. flavum is sporadically met in arid, rocky regions, in 
meadows and shrubberies, from the steppe area until the beech tree level (Ciocârlan, 2000). Allium saxatile Bieb. originating from the Pontic - Balkan area, is rarely met in Romania, mainly on rocky hills of the steppe and silvosteppe in Dobrogea (Ciocârlan, 2000).

Silene genus (Caryophyllaceae) has over 700 species in the Northern hemisphere in Europe, Asia and North of Africa (Bari, 1973; Greuter 1995 quoted by Sheidai et al., 2009). In the Romanian spontaneous flora approximately 40 species were identified 29 in Dobrogea (Oprea, 2005). Silene compacta Fischer. is an annual species, of Pontic Mediterranean origin. In Romania it is met rarely on the rocky coasts from the North of Dobrogea (Ciocârlan, 2000; Oprea, 2005). Silene supina M.Bieb. (syn. Silene spergulifolia (Wild) M.Bieb.) is considered rare in Romania and is usually encountered in stony areas in Tulcea, Mehedinți, Caraş Severin (Ciocârlan, 2000).

The aim of this article is to update information referring to the number of chromosomes in Romanian wild plants with ornamental use. Although there is already a number of cytogenetic studies regarding the Romanian indigenous flora, an update of the information is necessary either for confirming the existing data, either for identifying new possible forms, especially when, at the same species, variations of the chromosome number appear, determined by specific conditions of the origin area of the plants.

\section{Materials and methods}

The analysis regarding the chromosome number was done for species of Allium and Silene: Allium flavum L, Allium saxatile Bieb., Silene compacta L., Silene supina Bieb. The observations were done on populations originating from different areas, except the Silene compacta and Silene supina species, where the seeds were collected from only one population.
The number of chromosomes was determined from the roots of the young plants obtained from seeds harvested from their natural habitat, Dobrogea, area situated in the South-Eastern part of Romania (Fig. 1). Harvesting of seeds was done during 2009 - 2010.

Allium flavum L. has ornamental use due to its yellow flowers, grouped in umbelliferous inflorescences that bloom in July-August (Fig. 2). Seeds were harvested from two populations from the area of Măcin mountains (Turcoaia town, Tulcea county) and in Cheile Dobrogei (Constanța county).

Allium saxatile Bieb. is ornamental through its globular umbelliferous inflorescences, with white pinkish flowers. Flowering takes place in June-September (Fig. 3). The biological material (seeds) was harvested from two populations, respectively from the area of Măcin mountains (Turcoaia town, Tulcea county) and from Cheile Dobrogei.

Geographical characteristics (lat. N, long. E, approximate altitude) of settlements where the Allium taxa originate from are presented in Tab. 1.

The ornamental elements of Silene compacta Fischer. are the pink flowers, grouped in a compact capituliform inflorescence (Fig. 4), that bloom in summer (June-Au-

Tab. 1. Origin areas of Allium flavum and Allium saxatile populations

\begin{tabular}{|c|c|c|c|}
\hline Species & Origin & $\begin{array}{l}\text { Geographical } \\
\text { position }\end{array}$ & $\begin{array}{l}\text { Altitude } \\
(\mathrm{m})\end{array}$ \\
\hline \multirow{2}{*}{$\begin{array}{l}\text { Allium } \\
\text { flavum L. }\end{array}$} & $\begin{array}{l}\text { Turcoaia (Tulcea } \\
\text { county) }\end{array}$ & $45.10 \mathrm{~N} 28.18 \mathrm{E}$ & 290 \\
\hline & $\begin{array}{l}\text { Cheia (Cheile Dobrogei } \\
\text { - Constanța county) }\end{array}$ & $44.50 \mathrm{~N} 28.41 \mathrm{E}$ & 120 \\
\hline \multirow{2}{*}{$\begin{array}{l}\text { Allium } \\
\text { saxatile Bieb. }\end{array}$} & $\begin{array}{c}\text { Turcoaia (Tulcea } \\
\text { county) }\end{array}$ & $45.10 \mathrm{~N} 28.18 \mathrm{E}$ & 290 \\
\hline & $\begin{array}{l}\text { Cheia (Cheile Dobrogei } \\
\text { - Constanța county) }\end{array}$ & $44.50 \mathrm{~N} 28.41 \mathrm{E}$ & 120 \\
\hline
\end{tabular}

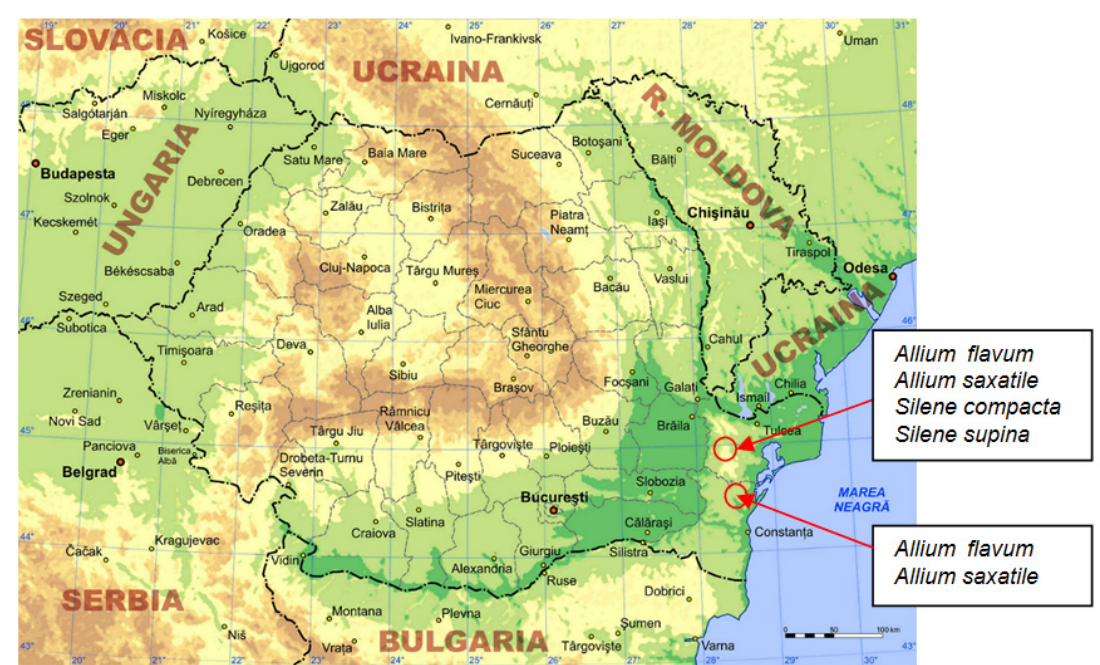

Fig. 1. Natural habitats of studied taxa (Romania)

(http://www.world-geographics.com/maps/europe/map-of-romania/) 
296

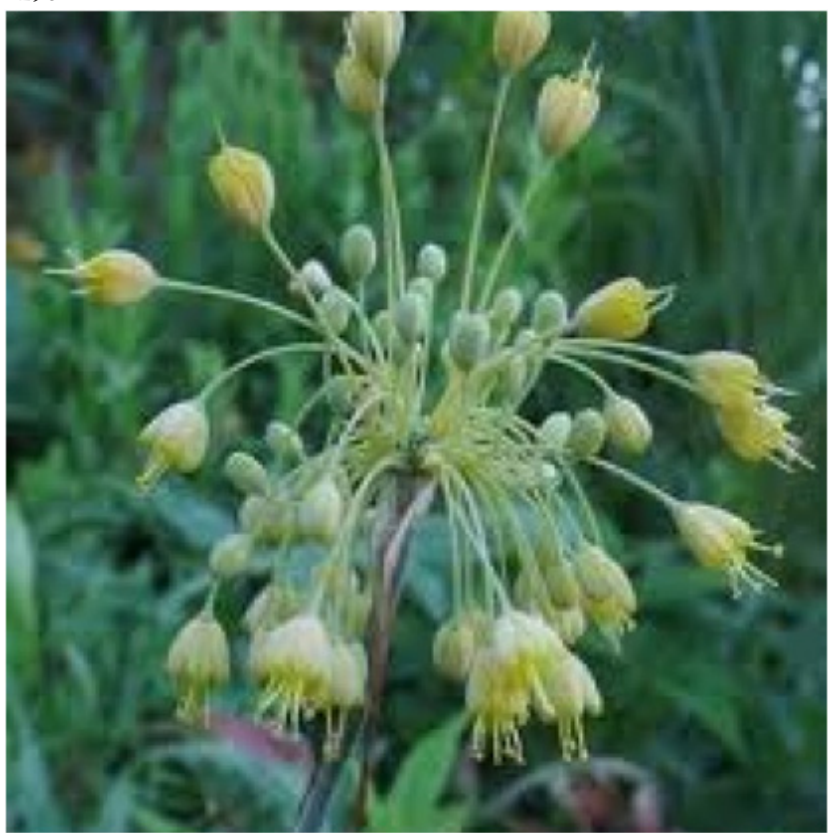

Fig. 2. Allium flavum (http://www.harperleyhallfarmnurseries. co.uk/image/cache/data/Allium\%20flavum-500x500.jpg)

gust). Seeds from a population in Măcin mountains, Turcoaia town (Tulcea county) were harvested. Silene supina M.Bieb. has a branched stem, while the flowers are grouped in inflorescences, with a short pedicel, a long, cylindrical calyx and white bifurcate petals (Fig. 5). The seeds were harvested from plants from o population in Măcin mountains, Turcoaia town (Tulcea county).

Geographical characteristics of the settlement where Silene taxa originate from are presented in Tab. 2.

\section{Chromosome analysis}

In order to study the number of chromosomes, temporary preparates from radicular meristem $(1-1.5 \mathrm{~cm}$ in length) of 3-7 days old plants were obtained. The seeds

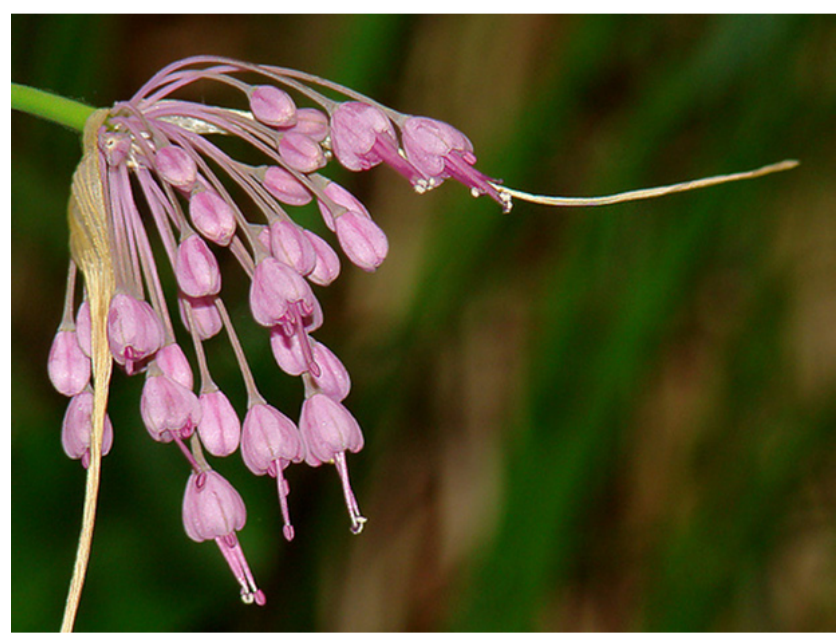

Fig. 3. Allium saxatile

(http://farm2.staticflickr.com /1038/1347242925_88042bd8be.jpg)

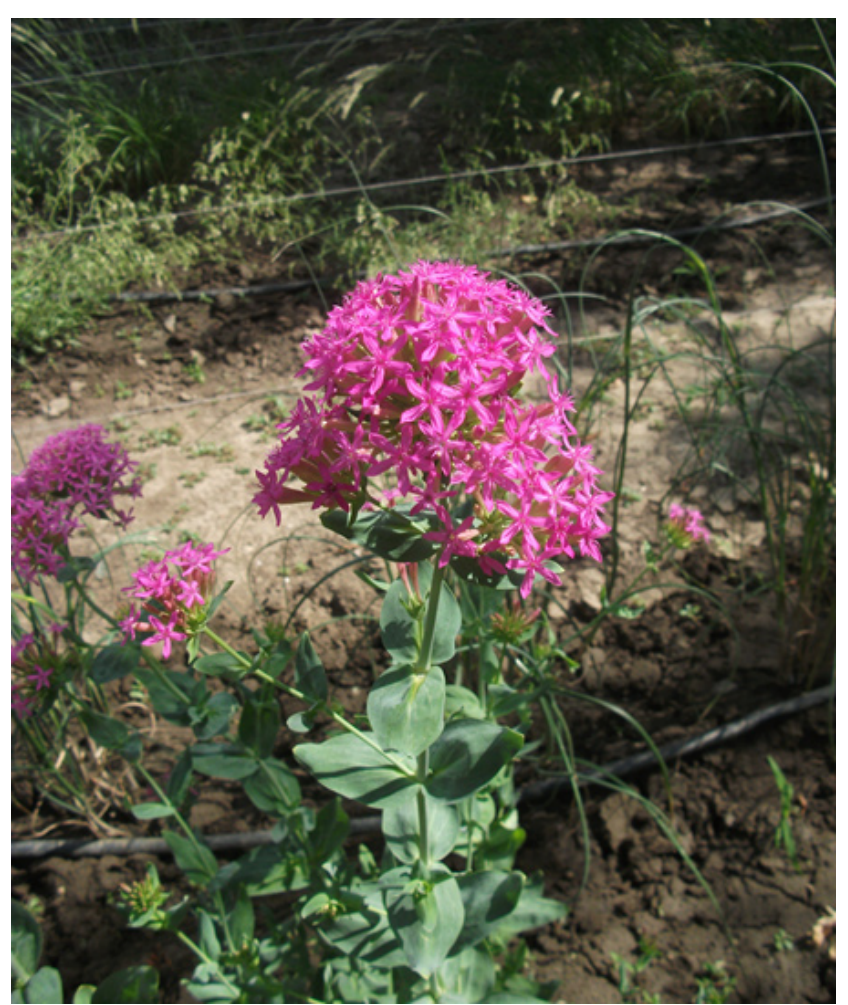

Fig. 4. Silene compacta (original)

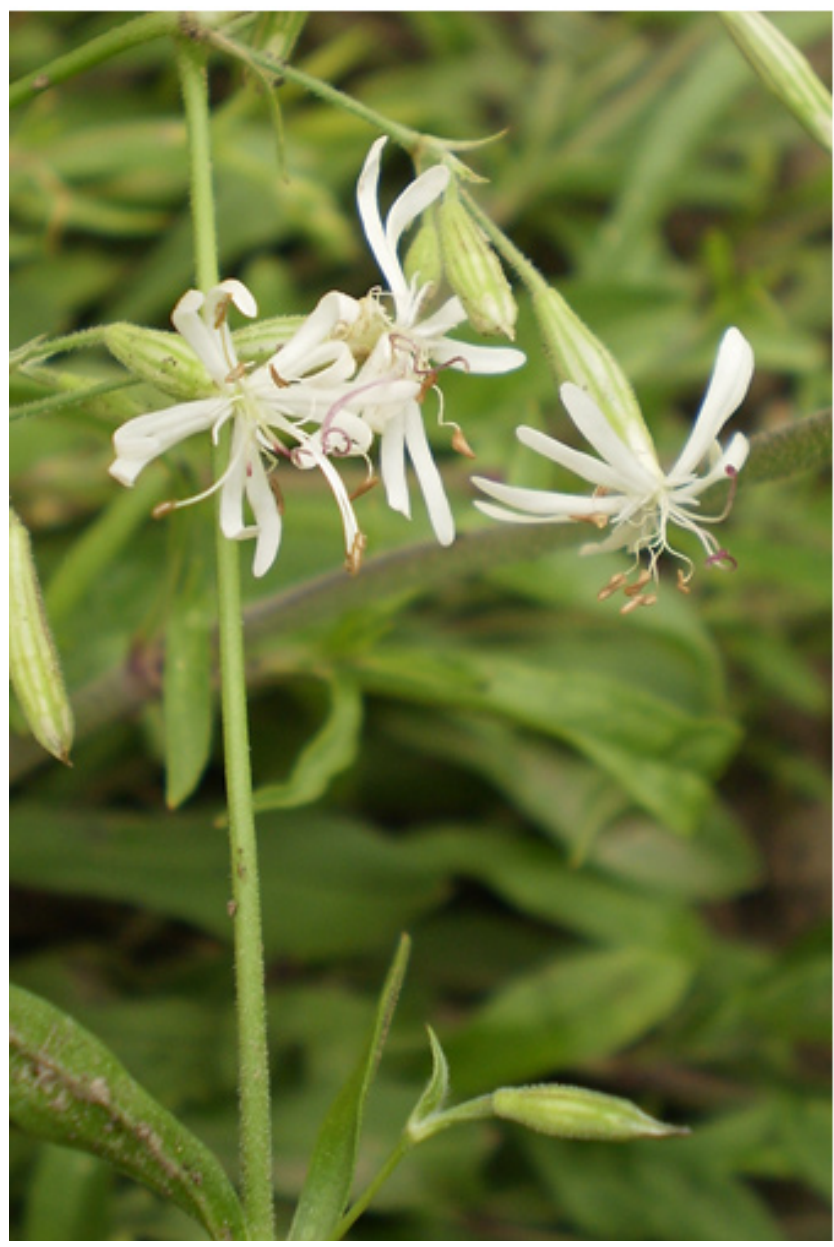

Fig. 5. Silene supina (original) 
Tab. 2. Origin areas of Silene compacta and Silene supina populations

\begin{tabular}{cccc}
\hline Species & Origin & $\begin{array}{c}\text { Geographical } \\
\text { position }\end{array}$ & $\begin{array}{c}\text { Altitude } \\
(\mathrm{m})\end{array}$ \\
\hline $\begin{array}{c}\text { Silene compacta } \\
\text { Fischer. }\end{array}$ & $\begin{array}{c}\text { Turcoaia } \\
\text { (Tulcea county) }\end{array}$ & $45.10 \mathrm{~N} 28.18 \mathrm{E}$ & 290 \\
$\begin{array}{c}\text { Silene supina } \\
\text { M.Bieb. }\end{array}$ & $\begin{array}{c}\text { Turcoaia } \\
\text { (Tulcea county) }\end{array}$ & $45.10 \mathrm{~N} 28.18 \mathrm{E}$ & 290 \\
\hline
\end{tabular}

were set to germinate in Petri dishes, on moist filter paper, at room temperature $\left(18-20^{\circ} \mathrm{C}\right)$. The stages of preparing the biological material were: prefixation, fixation, hydrolysis, staining and mounting the preparate on slides. Prefixation of biological material was done in the morning, between $8-10$, using colchicine $0.5 \%$, for 30 minute. Fixation was obtained using Carnoy I (glacial acetic acid: ethylic alcohol $96^{\circ} 1: 3$ ), for 24 hours, at $4^{\circ} \mathrm{C}$. Hydrolysis was done with clorhydric acid $1 \mathrm{~N}$, at $60^{\circ} \mathrm{C}$, for $14 \mathrm{~min}$., following a rinsing of the material taken out of the fixator with distilled water. Staining was done using the Feulgen method (T,îrdea and Leonte, 2003).

The samples were analyzed with Motic B1 optical microscope with a $100 \times$ lens, while the relevant images were captured with Motic video camera and processed with the specific software. The quantification of the number of chromosomes was performed in metaphasic cells from the total of 4000 cells analysed.

\section{Results and discussion}

Our analysis on the two populations of Allium flavum harvested in Dobrogea have confirmed the existence of diploid forms, 2n=16 (Fig. 6).

Moreover, the analysis conducted on plants of Allium saxatile from Tulcea and Constanța led us to draw the conclusion that the plants are diploid, with chromosome number of $2 n=16$ (Fig. 7).

The basic chromosome number for Allium genus is $x=7, x=8$ and even $x=9$, while polyploidy forms can have from $2 \mathrm{x}$ up to $16 \mathrm{x}$ (Bennett et al., 2000), the existence of a variable number of chromosomes being also possible (Baranyi et al., 1999; Fritsch and Friesen, 2002). The majority of Asian species are registered as tetraploid $2 n=32$, while the European ones are recorded as diploid, $2 n=16$ (Kawano and Nagai, 2005). Only one species has an octaploid form, Allium monophyllum (Fritsch and Astanova, 1998). A greater karyological stability is recorded in Allium ursinum and all bibliographical data mention its diploid form, 2n=14 (Baranyi et al., 1999; Draghia et al., 2010; Karpaviciene, 2007).

In Europe, Allium flavum L. has a variable number of chromosomes, being registered in its diploid, as well as in its tetraploid form $(2 n=16$, respectively $2 n=32)$, being characterized by a morphological diversity of homologue chromosomes. The existence of diploid and tetraploid populations, separated from a geographical as well as an

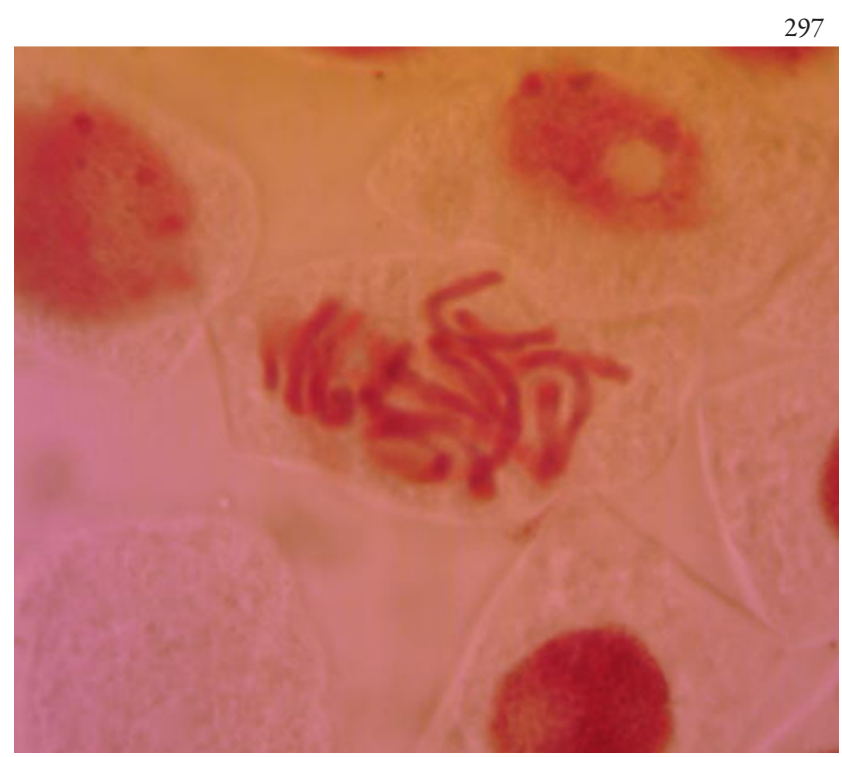

Fig. 6. Somatic metaphase in Allium flavum $(2 \mathrm{n}=16)$ (original)

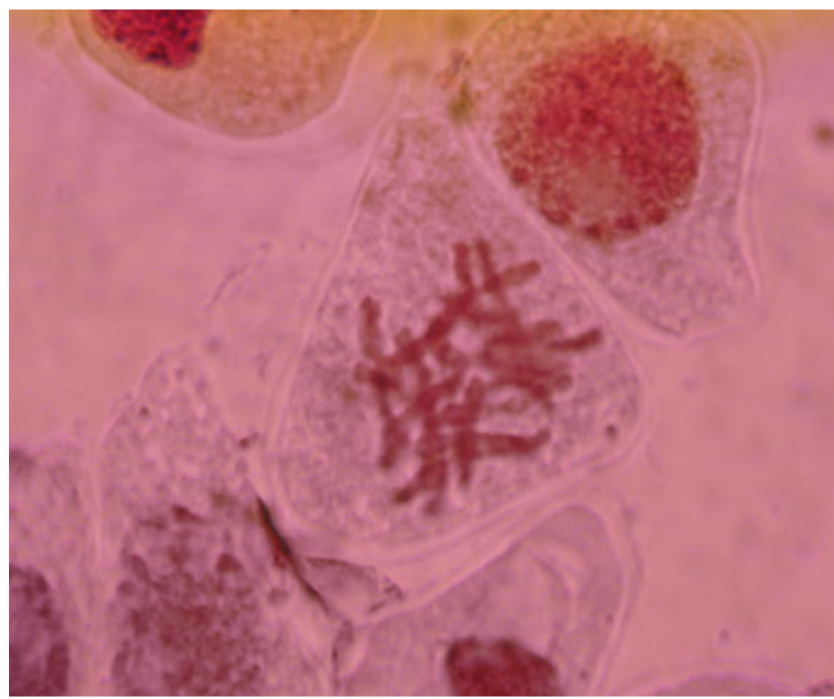

Fig. 7. Somatic metaphase in Allium saxatile $(2 \mathrm{n}=16)$ (original)

ecological point of view, has been confirmed by many authors. In some cases, B-chromosomes have been registered in diploid forms. Krahulcová (2003) reports the presence of diploid populations $(2 n=16+2 B)$ of Allium flavum in the South of Moravia, synthetizing at the same time, the results obtained by other authors, from different areas of Europe: diploid forms $(2 n=16)$ identified in Albania $(2 n=16+1 B$ : Baltisberger and Baltisberger, 1995; sec. Goldblatt and Johnson, 1998), Austria ( $2 n=16,2 n=16+1$ 2B: Dobeš and Vitek, 2000), France (Natarajan, 1978), Italy $(2 \mathrm{n}=16,2 \mathrm{n}=16+2 \mathrm{~B}$ : Capineri et al. sec. Goldblatt, 1984), Macedonia (Šopova, 1972 sec. Goldblatt, 1981), Serbia (Lovka, 1995), Romania (Jacobsen and Ownbey, 1977), Slovakia (Hindáková, 1970 sec. Májovský, Murín et al., 1987; Hrušovská-Osuská, 1988 sec. Májovský et al., 2000), Turkey ( $\mathrm{n}=8+1 \mathrm{~B}_{\mathrm{II}}$ : De Sarker et al., 1997, 2n=16: Özhatay, $1984 \mathrm{sec}$. Goldblatt, 1988); tetraploid forms $(2 n=32)$ identified in Mediterranean areas, in Spain (Ruiz 
298

Rejon, 1976) and Montenegro (van Loon Kieft, 1980); both diploid and tetraploid forms: in Bulgaria (van Loon and van Setten, 1982) and in Greece (Strid and Franzén, 1981; Tzanoudakis, Vosa, 1988 sec. Goldblatt and Johnson, 1991; Karavokyrou and Tzanoudakis, $1991 \mathrm{sec}$. Goldblatt and Johnson, 1994).

The information regarding the karyotype of the $\mathrm{Al}$ lium saxatile Bieb. species is insufficient, the specific literature having only data that mentions the presence of diploid plants, with the basic chromosomes number $\mathrm{x}=8$ $(2 \mathrm{n}=2 \mathrm{x}=16)$ (Ciocârlan, 2000; Ricroch et al., 2005)

The obtained results from the analyzed Silene compacta and Silene supina species $(2 \mathrm{n}=24)$ are similar to those recorded by other authors, in the case of taxa from other areas.

The analysis of plants harvested from Măcin Mountains (Turcoaia town) (Tab. 3), have confirmed the results found in specific literature (Fig. 8 and 9).

Cytogenetic studies of Silene genus were applied to species and populations from different geographical areas: Turkey (Martin et al., 2008; Minareci et al., 2009; Ozturk et al., 2009; Yildiz et al., 2006, 2009), Iran (Gholipour and

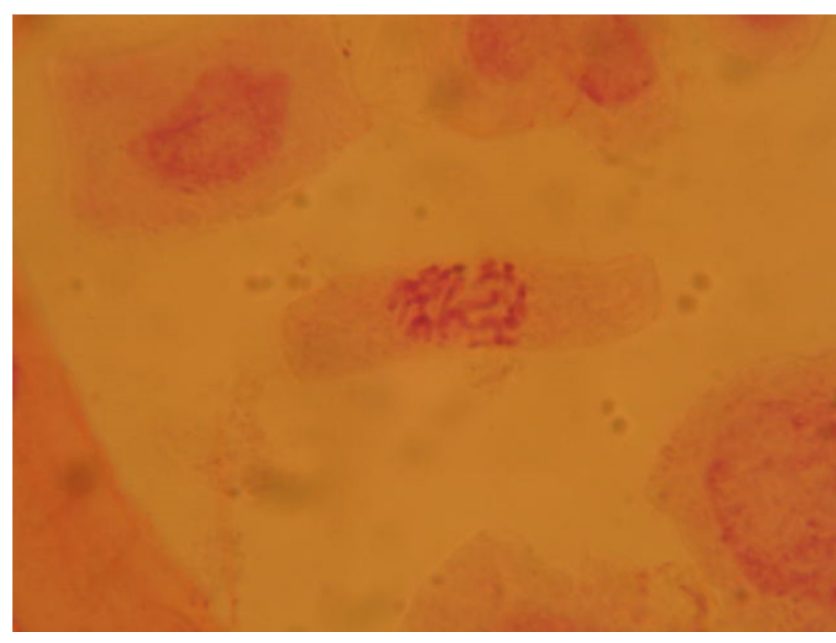

Fig. 8. Somatic metaphase in Silene supina $(2 \mathrm{n}=24)$ (original)

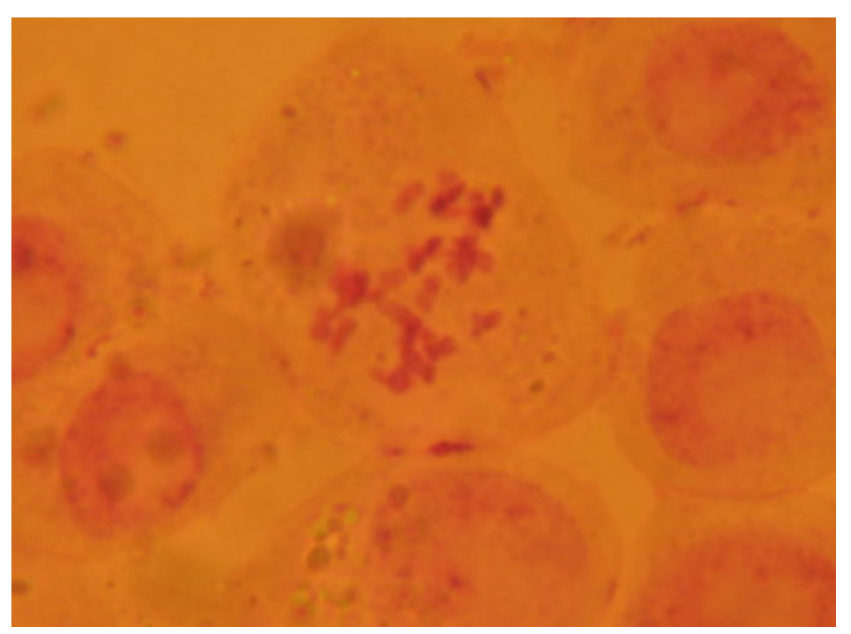

Fig. 9. Somatic metaphase in Silene compacta $(2 \mathrm{n}=24)$ (original)
Sheidai, 2010; Sheidai et al., 2008, 2009), Cypress (Yldiz and Gucel, 2006), Greece (Constantinidis et al., 2009), Bulgaria (Pavlova and Tocheva, 2004), North America (Popp and Oxelman, 2007) or other regions (Bari, 1973; Nersesian and Goukasian, 1995; Vogt and Oberprieler, 2009) as well as for Romanian species (Baltisberger and Widmer, 2009; Ciocîrlan, 2000; Ironside and Filatov, 2005).

The majority of the references in specialty literature show that diploid species $(2 n=2 x=20$ or $2 n=2 x=24)$ are more spread, then tetraploid forms $(2 n=4 x=48)$, hexaploid $(2 \mathrm{n}=6 \mathrm{x}=72)$ and that only some have a higher degree of polyploidy $2 \mathrm{n}=\mathrm{c} .96,120$ and 192 (Bari, 1973). Triploid forms are found in the Silene fortunei species (Heaslip, 1951, quoted by Sheidai, 2009). Furthermore, reports of $2 \mathrm{n}=18(\mathrm{x}=9)$ in the case of S. conica and S. lacera (Spova and Sekovski, 1982, quoted by Sheidai et al., 2009) or $2 \mathrm{n}=46(\mathrm{x}=23)$ for $S$. firma (Zhang, 1994, quoted by Sheidai et al., 2009). In Turkey, Ozturk et al. (2009) registers a different number of chromosomes in three $\mathrm{Si}$ lene species: Silene alba subsp. divaricata $2 \mathrm{n}=24$, Silene conoidea $2 n=20$ and $2 n=24$ for Silene otites.

In the case of $S$. compacta and $S$. supina, the literature specifies that the basic number of chromosomes is $x=12$ and that diploid forms $2 n=2 x=24$ exist in populations from Dobrogea, Romania (Ciocârlan, 2000), Turkey (Bari, 1973; Yildiz and Cirpici, 1996, quoted by Pavlova, 2004) and Greece (Strid and Franzen, 1983). The results are different from the ones obtained by Pavlova and Tosheva (2004), that report tetraploid forms $2 n=48$ chromosomes in populations of $S$. supina from Bulgaria (coast of the Black Sea).

\section{Conclusions}

The results obtained from the A. flavum, A. saxatile, $S$. compacta and $S$. supina taxa from populations located in the South-Eastern area of Romania (Dobrogea) are similar to the data reported for populations in other natural habitats. The two Allium species (A. flavum and A. saxatile) are diploid, with $2 \mathrm{n}=16$ chromosomes. The somatic number of chromosomes registered in $S$. compacta and $S$. supina species from Dobrogea (Turcoaia town) was $2 \mathrm{n}=24$.

\section{Acknowledgements}

This work was supported by CNCSIS - UEFISCU, project number PNII - IDEI 1233/2008 (Romania).

\section{References}

Anastasiu P, Negrean G (2006). Alien vascular plant in Dobrogea (Romania) and their impact on different types of habitats. Plants, fungal and habitat diversity investigation and conservation. Proceedings of IV BBC, Sofia 590-596 p.

Baltisberger M, Widmer A (2009). Karyological data of some angiosperms from Romania. Willdenowia 39, Botanic Gar- 
den and Botanical Museum Berlin-Dahlem 353-363 p.

Baranyi M, Greilhuber J (1999). Genome size in Allium: In quest of reproducible data. Ann Bot 83:687-695.

Bari EA (1973). Cytological studies in the genus Silene L. New Phytol 72:833-838.

Băra I, Rugină R, Băra CI (2003). The chromosomal number for rare species from Romania. Ann of the "Alexandru Ioan Cuza” University Genetics and Molecular Biology 4:62-70.

Bennett MD, Bhandol P, Leitch IJ (2000). Nuclear DNA Amounts in Angiosperms and their Modern Uses - 807 New Estimates. Ann Bot 86:859-909.

Boşcaiu M, Vincente O, Ehrendorfer F (1999). Chromosome number, karyotypes and nuclear DNA contents from perennial polyploidy groups of Cerastium (Caryophyllaceae). Plant System Evol 218:13-21.

Brullo S, Guglielmo A, Pavone P, Scelsi F, Terrasi CM (1996). Cytotaxonomic consideration of Allium fuscum Waldst. Et kff. (Liliaceae), a critical species of the european flora. Geobot Phytotax 31:465-472.

Ciocârlan V (2000). Flora ilustrată a României. (Illustrated Flora of Romania). Ceres Publishing House, Bucureşti, 1141 p.

Constantinidis T, Bareka EP, Kamari G (2002). Karyotaxonomy of Greek serpentine angiosperms. Bot J Linn Soc 139:109124.

Draghia L, Morariu A, Chelariu L (2010). Cytogenetic research regarding species with ornamental value identified in the North-East area of Romania. Cercetări Agronomice în Moldova 4(144):51-59.

Fritsch RM, Astanova SB (1998). Uniform karyotypes different sections of Allium L. subgen. Melanocrommyum (Webb \& Berth) Rouy from central Asia. Feddes repertorium 109(78):539-549.

Fritsch RM, Friesen N (2002). Allium Crop Science: Recent Advances I, 5-30 p. In: Rabinowich HD, Currah L (Eds.). Evolution, Domestication and Taxonomy, CABI Publishing.

Gholipour A, Sheidai M (2010). Further contribution to cytotaxonomy of the genus Silene L. (Sect. Auriculatae, Caryophyllaceae). Acta Biologica Szegediensis 54(2):111-115.

Ironside JE, Filatov DA (2005). Extreme population structure and high interspecific divergence of the Silene Y chromosome. Genetics 171(2):705-713.

Karpaviciene B (2007). Chromosome number of Allium from Lithuania. Ann Bot Fennici 44:345-352.

Kawano S, Nagai Y (2005). Life-history monographs of Japanese plants. 4: Allium victorialis L. ssp. platyphyllum (Makino) Hultén (Alliaceae) Syn. Allium victorialis L. var. platyphyllum Makino; A. latissimum Prokh. Plant Species Bio 20:219-225.

Krahulcová A (2003). Chromosome numbers in selected monocotyledons (Czech Republic, Hungary and Slovakia). Preslia 75:97-113

Loidl AE (1982). B-chromosomes in Allium flavum (Liliaceae) and some related species. Plant Syst Evol 139:197-207.

299

Martin E, Bağcı Y, Ertuğrul K, Dural H (2008). A karyological study on three taxa of Silene L. (Caryophyllaceae) by use of an image analysis system. Phytologia 90(1):3-14.

Minareci E, Yildiz K, Çirpici A (2009). Karyological studies in some species of the genus Silene (Caryophyllaceae). Cytologia $74(3): 245-252$.

Mraz P, Szelag Z (2004). Chromosome number and reproductive system in selected of Hieracium and Pilosella (Asteraceae) from Romania. Ann Bot Fen 41:405-414.

Ohri D, Pistrick K (2001). Phenology and genome size variation in Allium L. a tight correlation? Plant Biol 3:654-660.

Oprea A (2005). Lista critică a plantelor vasculare din România (Critical list of vascular plants in Romania). Publisher University “Al. I. Cuza” Iasi, 668 p.

Ozturk M, Martin E, Dinc M, Duran A, Ozdemir A, Cetin O (2009). A cytogenetical study on some plants taxa in Nizip region (Aksaray, Turkey). Turk J Biol 33:35-44.

Pavlova D, Tosheva A (2004). Mediterranean chromosome number reports. Flora Mediterranea 14 (Report 13821386):429-430.

Pavlova D (2008). Mediterranean chromosome number reports (Caryophyllaceae) 583-586 p. In: Kamari G, Blanche C, Siljak-Yakovlev S (Eds.). Flora Mediterranea 18, http://www. academia.edu

Popp M, Oxelman B (2007). Origin and evolution of North American polyploidy Silene (Caryophyllaceae). Am J Bot 94(3):330-349.

Ricroch A, Yockteng R, Brown SC, Nadot S (2005). Evolution of genome size across some cultivated Allium species. Genome 48:511-520.

Sălăgeanu Gh, Bavaru A, Klaus F (1978). Reservations, monuments and natural beauties of Constanta county. Natural Sciences Museum Complex Constanta. Polygraphic Institute "Filaret", Bucharest, 102 p.

Sheidai M, Nikoo M, Gholipour A (2008). Cytogenetic variability and new chromosome number reports in Silene L. species (Sect. Lasiostemones, Caryophyllaceae). Acta Biol Szegediensis 52(2):313-319.

Sheidai M, Bahmani F, Enayatkhani M, Gholipour A (2009). Contribution to cytotaxonomy of Silene: chromosome pairing and unreduced pollen grain formation in sec. Sclerocalycinae. Acta Biol Szegediensis 53(2):87-92.

Stace CA (1998). Plants taxonomy and biosystematics. Cambridge University Press, Blackwell Science, Ltd., $2^{\text {nd }}$ Edition, $272 \mathrm{p}$.

Strid A, Franzen R (1983). Chromosome numbers in flowering plants from Greece. Willdenowia 13:329-333.

Tăcină A (1980). Cytotaxonomic investigations regarding two endemic species in Romanian flora. Rev Roumaine Biol, Biol Végét Bucureşti 117-120.

Țîrdea Gh., Leonte C. (2003). Citogenetica vegetală - metode de laborator. Cap. I. Tehnica microscopică utilizată în tehni- 
300

ca de citogenetică. (Plant cytogenetics - laboratory methods. I, p 3-33 In: Microscope analysis in cytogenetic techniques). Publisher Ion Ionescu de la Brad Iasi, Romania.

Yildiz K, Gucel S (2006). Chromosome numbers of 16 endemic plant taxa from Northern Cyprus. Turk J Bot 30:181-192.

Yildiz K, Minareci E, Çirpici A (2009). Karyotypic study on Silene, section Lasiostemones species from Turkey. Caryologia 62(2):134-141.

Yousaf Z, Shinwari ZK, Qureshi RA, Khan MA., Gilani S (2004). Can complexity of the genus Allium L., be resolved through some numerical techniques? Pak J Bot 36(3):487501.
Vit B, Fargasova A (2007). Atlas of seeds and fruits of Central and East-European flora. The Carpathian Montains Region. Springer $199 \mathrm{p}$.

Vogt R, Oberprieler C (2009). Chromosome numbers of North African phanerogams. IX. In: Marhold K (Ed.). IAPT/ IOPB chromosome data 8. - Taxon 58: 1282-1283, E3-E9. 